administered by continuous intravenous infusion in the presence of impaired renal function. ${ }^{2}$

We suggest that our patient developed a severe irreversible encephalopathy secondary to cephaloridine administration in the presence of acute renal failure, which may itself have been related to the drug. Recognition of the encephalopathic potential of cephaloridine is important, especially in the presence of impaired renal function.

We thank $\operatorname{Dr} M \mathrm{~K}$ Ward for permission to report this case.

1 Smith H, Lerner PI, Weinstein L. Neuro toxicity and massive intravenous therapy with penicillin. Arch Intern Med 1967;120:47-53.

2 Bloomer HA, Barton LJ, Maddock RK. Penicillin induced encephalopathy in uraemic patients. $\Im A M A 1967 ; 200: 121-3$.

3 Yoshioka H, Nambu H, Fujita $M$, et al. Convulsions following intrathecal cephaloridine. Infection $1975 ; 3: 123-4$.

4 Vianna N, Kaye D. Penetration of cephalothin into the spinal fluid. Am $\mathcal{J}$ Med Sci 1967;254:216-20.

5 Welles JS, Gibson WR, Harris PN, et al. Toxicity, distribution and excretion of cephaloridine in laboratory animals. Antimicrob Agents Chemother 1965;5:863-9.

(Accepted 13 May 1981)

Royal Victoria Infirmary, Newcastle upon Tyne NE1 4LP ROY TAYLOR, BSC, MRCP, registrar, department of medicine RICARDO ARZE, MD, research associate, department of medicine R GOKAL, MD, MRCP, lecturer, department of medicine

J C STODDART, MD, FFARCS, consultant in charge, intensive therapy unit

\section{Death during play: a study of playground and recreation deaths in children}

Childhood injuries caused by playground equipment may be severe, but few studies have been undertaken to place this problem in perspective. Playground deaths among children (excluding motorvehicle accidents and drownings) have not previously been studied, and only one large series of injuries not resulting in death has been reported. ${ }^{2}$

Recently adventure playgrounds have become popular, with a corresponding proliferation of equipment designed to develop physical confidence, balance, curiosity, and co-ordination. In general, such new playgrounds tend to be well supervised and are safe and exciting places for children; casualty officers, however, see a constant flow of children who have been injured on slippery slides, ${ }^{1}$ swings, see-saws, and other equipment. We were concerned at the number of children injured in playground accidents attending casualty departments and report here a study of deaths due to this cause.

\section{Methods and results}

Children (age range 0-15 years) were included in the study if $(a)$ they had died as a result of an injury received while playing and $(b)$ their death had occurred at school or in a private playground, public park, recreation area, or their own garden. Children were excluded if a motor vehicle or bicycle had played a part in the accident or if they had drowned. Cases were identified and details obtained from the coroner's records and forensic records of the Institute for Forensic Pathology and the Laboratory of Microbiology and Pathology, Brisbane. Every death of a child (from whatever cause) during 1976-80 (inclusive) was initially reviewed, and cases satisfying the above criteria were selected for study. All such cases were checked individually for an association between accidental injury during play and recreation.

Brisbane is a modern, urban metropolis of one million people, of whom 266000 were children aged under 15 years at the mid-survey point. Thus the survey was a total population study, without selection, of fatal recreational accidents to children in a modern Western society.

Fourteen children (nine boys, five girls) died during play over the five-year period (table). This gives an annual population incidence of $0 \cdot 3 / 100000$ and an annual age-specific child population incidence (0-15 years) of $1 \cdot 1 / 100000$. No specific modal age was particularly at risk. Three children died while playing with ropes: two were strangled while playing in trees and one while swinging from a rope attached to a brick chimney at a derelict site. Only two children were killed in accidents caused by playground equipment: in both cases the equipment was not attached firmly to the ground and fell and fatally crushed the child. Electrocution is now rare in children. In one of the two cases in this series a model aircraft became entangled in overhead electric wires and a 15-year-old boy was electrocuted. Only one child died from injuries received in a school playground, this being the result of him colliding with another child while both were running.

Summary of 14 deaths among children at play, 1976-80

\begin{tabular}{|c|c|c|c|}
\hline $\begin{array}{l}\text { Type of } \\
\text { accident }\end{array}$ & $\begin{array}{l}\text { No of } \\
\text { cases }\end{array}$ & $\begin{array}{l}\text { Age of victims } \\
\text { (years) }\end{array}$ & Traumatic agents \\
\hline Crush injury & 5 & $12,9,9,9,4$ & $\begin{array}{l}\text { Rope, chimney; hay cart; slippery slide; } \\
\text { monkey bars; amusement-arcade } \\
\text { machine }\end{array}$ \\
\hline $\begin{array}{l}\text { Strangulation } \\
\text { Electrocution }\end{array}$ & $\begin{array}{l}3 \\
2\end{array}$ & $\begin{array}{l}12,5,2 \\
15,1\end{array}$ & $\begin{array}{l}\text { Rope, tree (two cases); laundry trolley } \\
\text { Overhead power lines, model aeroplane; } \\
\text { electrical wire, wet grass }\end{array}$ \\
\hline $\begin{array}{l}\text { Fall } \\
\text { Impact } \\
\text { Kick }\end{array}$ & $\begin{array}{l}2 \\
1 \\
1\end{array}$ & $\begin{array}{l}14,1 \\
7\end{array}$ & $\begin{array}{l}\text { Height; horse-riding } \\
\text { Collision between two boys in playground } \\
\text { Horse-riding }\end{array}$ \\
\hline
\end{tabular}

\section{Comment}

Current legislation concerning playground equipment, and current practices with respect to the safety of children during recreational activities, are obviously effective since no child died as the result of an accident in an adventure playground, in a city of one million people, over the five-year survey period.

In providing an enriched, adventurous environment for children a balance has to be struck between safety on the one hand and offering the child a stimulating and exciting play environment (supervised) on the other. Three-quarters of the injuries reported in the large Sheffield study $^{2}$ were trivial; $10 \%$, however, were serious enough to warrant admission to hospital. Our study indicates that it is not primarily problems with equipment or its design that causes serious trauma during play but rather inadequate supervision while children are experimenting and being adventurous in what is largely an unmodifiable environment.

Attention to design and further tightening of safety legislation regarding the installation of recreational equipment, child adventure playgrounds, and so on are obviously important and an essential baseline for child safety; but this will not reduce the age-specific incidence rate below about one per 100000 per year.

As in all types of accident prevention there are three possibilities -namely, education, improvement in ergonomic features and design, and safety legislation. In child recreational safety these three approaches are mutually inclusive. ${ }^{3}$ With major community resources being directed against fatal motor-vehicle accidents and drownings in children, increasing attention must be paid to other accidents ranking as important causes of serious child trauma, such as suffocation, burns, and falls ( $P$ O'Connor, for the Child Accident Prevention Foundation of Australia, unpublished data).

Non-accidental injury (the syndrome of child abuse and neglect) is often attributed by parents to the collapse of or a fall from some type of child's play equipment. ${ }^{4}$

This study has shown that the widespread provision of adventure playgrounds for young children does not result in any appreciable increase in fatal accidents to children at play if they are properly planned and properly supervised.

Requests for reprints should be sent to $\mathrm{Mr}$ James Nixon, Department of Child Health, Royal Children's Hospital, Herston 4029, Brisbane, Queensland, Australia.

${ }^{1}$ Sullivan K. Slippery slide accidents. Med $\mathcal{f}$ Aust 1979;1:342.

2 Illingworth C, Brennan P, Jay A, et al. 200 injuries caused by playground equipment. $B r$ Med f 1975 ;iv :332-4.

${ }^{3}$ Hurst J, Ellis $M$. Fatal accidents to children: implications for prevention. Med ₹ Aust 1977;2:768-70.

4 Wight BW. The control of child-environment interaction: a conceptual approach to accident occurrence. Pediatrics $1969 ; 44: 799-801$.

(Accepted 19 May 1981)

Department of Child Health, Royal Children's Hospital, Brisbane, Queensland, Australia

JAMES NIXON, BA, lecturer in medical social work

JOHN PEARN, FRCP, FRACP, reader in child health

Institute of Forensic Pathology, State Health Department, Brisbane, Queensland, Australia

IAN WILKEY, MB, FRCPA, director 